Jurnal Konstruksi Hukum | ISSN: 2746-5055

Vol. 2, No. 1, Januari $2021 \mathrm{Hal}$. 196-201 | Tersedia online di https://www.ejournal.warmadewa.ac.id/index.php/jukonhum

DOI: https://10.22225/jkh.2.1.2996.196-201

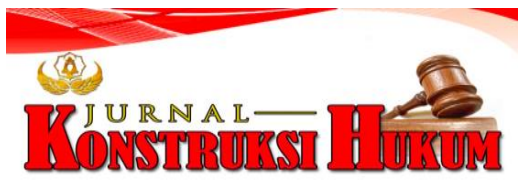

\title{
TANGGUNG JAWAB PIHAK ASURANSI TERHADAP PERJANJIAN KREDIT BANK DALAM HAL DEBITUR MENINGGAL DUNIA
}

\author{
Ni Putu Purnama Wati, Ni Luh Made Mahendrawati, Desak Gde Dwi Arini \\ Fakultas Hukum Universitas Warmadewa, Denpasar-Bali, Indonesia
}

\begin{abstract}
Abstrak
Perjanjian kredit biasanya dibarengi perjanjian agunan serta perjanjian asuransi. Perjanjian asuransi inilah menjadi sarana pengalihan risiko bagi bank, khususnya asuransi jiwa dalam hal debitur meninggal dunia, disamping kredit juga dapat jatuh kepada ahli waris jika debitur meninggal dunia sebelum melunasi sisa kreditnya. Penelitian in bertujuan untuk menganalisis akibat Hukum terhadap Perjanjian Kredit Bank dalam hal Debitur Meninggal Dunia dan mengetahui tanggung Jawab Pihak Asuransi terhadap Perjanjian Kredit Bank dalam hal Debitur Meninggal Dunia. Penelitian ini menggunakan metode penelitian normatif dengan pendekatan perundang-undangan dan pendekatan konseptual. Hasil penelitian menunjukan bahwa akibat hukum perjanjian kredit dalam hal debitur meninggal dunia ada dua kemungkinan yaitu kredit jatuh ke ahli waris sebagaimana diatur dalam pasal 833 KUHPerdata (Burgerlijk Wetboek) atau jaminannya dieksekusi pihak bank, serta kemungkinan kedua adalah kredit hapus karena adanya klausula asuransi jiwa atau perjanjian asuransi jiwa dengan syarat banker's clause, artinya disini pihak asuransi harus bertanggung jawab melunasi sisa utang debitur yang meninggal sesuai syarat dan ketentuan dalam polis, jika tidak maka pihak yang berkepentingan dapat mengajukan somasi hingga menggugat pihak asuransi. Dari hal tersebut, simpulannya para pihak haruslah memahami betul isi dari perjanjian kredit yang dibuat, sehingga nantinya jika terjadi risiko tersebut, maka ada kejelasan terhadap pembayaran sisa utang debitur.
\end{abstract}

Kata Kunci: Perjanjian Kredit Bank, Debitur Meninggal Dunia, Ahli Waris Debitur, Tanggung Jawab Pihak Asuransi

\begin{abstract}
Credit agreements are usually accompanied by a collateral agreement and an insurance agreement. This insurance agreement is a means of transferring risk for the bank, especially life insurance in the event of a debtor's death, besides credit can also fall to the heirs if the debtor dies before paying off the remaining credit. This study aims to analyze the legal consequences of the Bank's Credit Agreement in the event that the Debtor dies and to find out the responsibility of the Insurance Party for the Bank's Credit Agreement in the event the Debtor dies. This study uses a normative research method with a statutory approach and a conceptual approach. The results show that the legal consequence of the credit agreement in the event that the debtor dies, there are two possibilities, namely that the credit goes to the heirs as regulated in article 833 of the Civil Code (Burgerlijk Wetboek) or the guarantee is executed by the bank, and the second possibility is that the credit is written off due to a life insurance clause or a life insurance agreement with a banker's clause, which means that the insurance company must be responsible for paying off the remaining debts of the debtor who died according to the terms and conditions of the policy, otherwise the interested party can file a summons to sue the insurance company. From this, the conclusion is that the parties must fully understand the contents of the credit agreement made, so that later if this risk occurs, there will be clarity on the payment of the debtor's remaining debt.
\end{abstract}

Keywords: Bank Credit Agreement, Debtor Died, Debtor Heir, Responsibilities of the Insurance Party

\section{PENDAHULUAN}

Perjanjian merupakan suatu peristiwa hukum dimana seseorang atau lebih berjanji kepada orang lain untuk berbuat sesuatu, atau pun untuk tidak berbuat sesuatu (Subekti 2005). Perjanjian ada banyak macamnya tergantung kebutuhan kita, salah satunya perjanjian kredit. Menyalurkan kredit merupakan cara bank untuk memperoleh keuntungan. Perjanjian kredit bank merupakan perjanjian baku yang telah ditetapkan secara sepihak oleh pihak bank. Dalam pemberian kredit bank terdapat banyak sekali risiko, sehingga bank perlu menerapkan prinsip kehati-hatian. Sebagai contoh risiko dalam hal debitur meninggal dunia sebelum sempat melunasi sisa hutangnya, ini terkait nasib sisa hutang debitur.

Dalam hal debitur meninggal dunia selama selama kredit masih berjalan ahli waris mempunyai kewajiban dalam hal pembayaran hutang, hibah wasiat, dan lain-lain dari pewaris, sebagaimana pasal 
833 ayat (1) KUHPerdata. Namun terdapat kekaburan norma dalam pasal 833 (1) tersebut dalam frasa "dengan sendirinya". Tidak ada kejelasan apakah ahli waris harus menerima dengan pasrah begitu saja seluruh warisan termasuk hutang yang dibebankan padanya, ataukah pasal tersebut memiliki maksud bahwa pemberian warisan (khususnya pembebanan utang) tersebut hanyalah secara formil atas dasar hukum saja karena di sisi lain ahli waris memiliki hak berpikir serta boleh menentukan sikap apakah akan menerima atau menolak warisan yang diberikan padanya atau dibebankan padanya (pasal 1023 KUHPedata). Selain hal tersebut dalam prakteknya juga banyak perjanjian kredit bank sudah mencantumkan klausula asuransi jiwa dengan syarat banker's clause atau meminta calon debitur untuk ikut serta dalam polis asuransi jiwa sebagai solusi jika debitur meninggal dunia sebelum melunasi utang-utangnya, sehingga bank mengalihkan risikonya kepada pihak asuransi jiwa.

\section{METODE PENELITIAN}

Penelitian menggunakan penelitian hukum normatif dengan melihat peristiwa atau perbuatan hukum yang ada di dalam masyarakat (Marzuki 2011; Soekanto and Mamudji 2003) dan melihat peraturanperaturan hukum serta pendekatan yang digunakan yaitu dengan mempergunakan pendekatan perundang-undangan dan pendekatan konsep Sumber data dalam pengkajian permasalahan hukum tersebut dengan sumber bahan hukum. Bahan hukum yang digunakan adalah bahan hukum primer, bahan hukum sekunder, dan bahan hukum tersier (Ahmad 2008). Metode yang digunakan dalam pengumpulan bahan hukum adalah dengan cara mengumpulkan, mengkaji, dan mengolah secara sistematis bahan-bahan kepustakaan dan dengan menganalisis peraturan perundang- undangan. Selanjutnya, diolah dan dianalisis secara sistematis dengan menggunakan metode argumentasi hukum berdasarkan logika hukum deduktif dan induktif. Hasil analisis dipaparkan secara deskriptif, dengan harapan dapat menggambarkan secara jelas mengenai tanggung jawab pihak asuransi terhadap perjanjian kredit bank dalam hal debitur meninggal dunia, sehingga diperoleh gambaran yang menyeluruh tentang permasalahan yang diteliti.

\section{HASIL DAN PEMBAHASAN}

\section{Akibat Hukum Terhadap Perjanjian Kredit Bank Dalam Hal Debitur Meninggal Dunia}

Bank adalah badan usaha yang menghimpun dana dari masyarakat dalam bentuk simpanan dan menyalurkannya kepada masyarakat dalam bentuk kredit dan bentuk-bentuk lainnya dalam rangka meningkatkan taraf hidup rakyat banyak (Gunartha 2013). Perjanjian kredit bank merupakan salah satu contoh perjanjian baku yang telah ditetapkan sepihak oleh pihak bank. Perjanjian Kredit adalah perjanjian mengenai pemberian fasilitas Kredit dari pihak bank kepada debitur (Indriani 2018). Jika dilihat dari syarat sahnya perjanjian itu dibuat yaitu khususnya pada poin kesepakatan para pihak, maka sebenarnya klausula baku pada perjanjian kredit merupakan kecacatan kehendak. Mengingat seharusnya terdapat negosiasi atau perundingan antara para pihak untuk menentukan isi dari perjanjian namun disini isi perjanjian telah dibuat secara sepihak oleh pihak bank, dan nasabah debitur hanya memiliki pilihan untuk menerima atau menolaknya.

Penting untuk memahami keseluruhan isi perjanjian yang dibuat oleh para pihak terutama disini dalam hal perjanjian kredit bank, calon nasabah debitur harus memahami betul isinya, sehingga calon nasabah debitur tidak dianggap lemah dan mudah diperdaya oleh oknum-oknum bank yang tidak bertanggung jawab. Sehingga klausula-klausula seperti rincian jumlah angsuran pokok, bunga yang harus dibayar, jangka waktu pinjaman, jatuh tempo, hingga mengenai hal-hal yang dapat terjadi diluar kehendak seperti jika debitur meninggal dunia apakah ahli waris yang menanggung utang-utangnya atau ada asuransi sebagai penjamin sisa utang, bagaimana sistemnya, apakah system banker's clause atau tidak. Inilah hal-hal yang riskan dan perlu dipahami betul oleh para pihak khususnya calon nasabah debitur.

Seperti hal terjadi sesuatu diluar kehendak para pihak yaitu dalam hal debitur meninggal dunia sebelum sempat melunasi seluruh pinjamannya, maka akibat hukum yang dapat terjadi terhadap perjanjian kredit yang telah dibuat adalah perjanjian kredit hapus sehingga utang lunas dikarenakan pembayaran melalui pihak ketiga yaitu lembaga asuransi sebagai lembaga peralihan risiko jika sebelumnya telah diatur dalam isi perjanjian, dan debitur telah membayar premi asuransi bersamaan dengan utangnya tiap bulannya, atau utang juga dapat jatuh kepada ahli warisnya sebagaimana diatur dalam ketentuan pasal 833 KUHPerdata. 
Jika dalam perjanjian kredit tersebut tidak mencantumkan klausula mengenai asuransi jiwa, maka ketentuan pasal 833 KUHPerdata dapat menjadi dasar hukum untuk nasib sisa kredit debitur. Namun masih terdapat kekaburan norma mengenai ketentuan pasal 833 KUHPerdata tersebut, bahwa dinyatakan di dalamnya ahli waris dengan sendirinya karena hukum mendapatkan warisan termasuk utang-piutang pewaris yang meninggal. Dari sini kita dapat melihat frasa "dengan sendirinya karena hukum" masih memiliki arti yang multitafsir, sebut saja yang pertama dapat dipahami bahwa secara otomatis ahli waris menerima tanpa ada celah penolakan semua warisan yang diberikan dan dibebankan padanya, kedua dapat diartikan bahwa ahli waris secara hukum menanggung semua warisan pewaris secara formil namun tetap memiliki hak berpikir untuk menerimanya atau menolaknya secara materiil.

Mengingat dalam pasal 1023 KUHPerdata ahli waris memiliki hak berpikir terkait harta peninggalan termasuk utang pewaris selama empat bulan lamanya. Namun, tetap hal ini harus sesuai prosedur yaitu harus dicatat oleh Panitera Pengadilan. Sehingga jika masa waktu empat bulan telah habis, maka ahli waris harus menentukan sikap dengan menyatakan salah satu hal berikut (Suparman 2018).

1. Menerima warisan tanpa syarat atau menyeluruh

Bahwa berdasarkan pasal 1045 KUHPerdata setiap orang tidak berkewajiban untuk menerima harta warisan. Akibat dari menerima warisan secara penuh maka ahli waris bertanggung jawab sepenuhnya atas segala kewajiban yang melekat pada warisan tersebut, termasuk utang pewaris.

2. Menerima warisan dengan syarat atau pencatatan (Beneficiaire aanvaarding); berarti apabila dalam pencataatan serta pengecekan harta warisan tersebut lebih banyak pasiva daripada aktiva, maka ahli waris tidak dapat mempertanggungjawabkannya. Jadi ahli waris hanya bertanggung jawab atas utang pewaris sebatas jumlah harta warisan yang ia peroleh saja. Jadi, ada beberapa pengertian penerimaan berdasarkan pasal 1032 KUHPerdata yaitu sebagai berikut:

a. Ahli waris tidak wajib untuk membayar utang pewaris melebihi jumlah harta warisan yang ia terima;

b. Ahli waris membebaskan diri dari utang pewaris dengan menyerahkan warisan kepada kreditur;

c. Harta kekayaan pribadi ahli waris dengan harta warisan yang ia terima dipisahkan dan tidak dapat dicampur. Maka jika kreditur ingin menuntut dan menggugat hanya sebatas terkait jumlah utang saja, dan utang ini selanjutnya dibayar dengan harta warisan pewaris, jika ada sisa barulah menjadi hak ahli waris.

3. Menolak warisan (Verwerping)

Penolakan harta warisan dapat terjadi bila terdapat harta warisan yang terbuka. Akibat dari ditolaknya warisan, maka ahli waris dianggap tidak pernah menjadi ahli waris, dan hal ini berlaku surut. Apabila penolakan warisan oleh ahli waris merugikan kreditur (jika terdapat utang-utang dari pewaris), maka kreditur dapat meminta kepada hakim agar diberi kuasa untuk menggantikan ahli waris dan memperoleh harta warisan itu atas nama dan untuk kedudukan ahli waris.

Jadi dari beberapa hal tersebut di atas maka jika debitur meninggal dunia sebelum melunasi utangutangnya maka ahli waris dapat menentukan sikap terkait warisan yang ditinggalkan pewaris, dengan syarat melapor dan menyatakan dimuka hakim bahwa ia hendak menggunakan hak berpikirnya selaku ahli waris untuk menentukan sikap terhadap warisan yang ditinggalkan pewaris. Pihak bank selaku kreditur tidak dapat memaksa ahli waris melunasi utang-utang pewaris sebelum ahli waris menyatakan menerima warisan pewaris secara penuh.

Disamping masalah ahli waris terkait pertanggungjawaban utang debitur, ada juga lembaga peralihan risiko yaitu lembaga asuransi yang dapat menjamin pembayaran atau pelunasan utang-utang debitur yang meninggal sebelum sempat melunasi utang-utangnya. Namun hal ini haruslah sudah diatur sebelumnya dalam isi perjanjian kredit, atau mungkin sebelumnya debitur telah terikat perjanjian asuransi jiwa terhadap lembaga asuransi. Maka pihak bank selaku kreditur harus jeli terkait beberapa risiko yang nantinya dapat terjadi dalam hal pemberian kredit, sehingga dapat ditangani dengan cepat. Asuransi jiwa pada umumya hanya mengenal pihak penanggung (perusahaan asuransi), 
pihak tertanggung (orang yang jiwanya dipertanggungkan), dan pihak penerima manfaat/yang ditunjuk (pihak yang berhak menerima pembayaran uang santunan), biasanya ahli waris dari tertanggung (Mursid 2018).

\section{Tanggung Jawab Pihak asuransi Terhadap Perjanjian Kredit Bank Dalam Hal Debitur Meninggal Dunia}

Perjanjian kredit biasanya tidak dapat berdiri sendiri melainkan harus dilengkapi dengan adanya perjanjian agunan serta perjanjian asuransi, walaupun perjanjian dapat dibuat secara lisan atau tulisan, ada baiknya dibuat secara tertulis dalam bentuk akta, sehingga memiliki kekuatan hukum yang kuat dan menjadi bukti sempurna. Polis asuransi sebagai perjanjian asuransi sebaiknya tertulis dalam bentuk akta sehingga memberikan jaminan perlindungan hukum terhadap perbuatan hukum yang dilakukan para pihak (pasal 255 ayat 1) KUHD). Jaminan merupakan langkah antisipatif dalam menarik kembali dana yang telah disalurkan kepada debitur (Pambudi and Pujiyono 2016).

Dalam perjanjian asuransi khususnya disini asuransi jiwa yang mana tidak dapat dilepaskan dari perjanjian kredit yang ada, para pihak yang menjadi sentral di dalamnya yaitu pihak asuransi selaku penanggung, nasabah debitur selaku tertanggung, dan pihak bank sebagai pemegang polis asuransi. Pada dasarnya pihak tertanggung hanya perlu menyetujui dan menandatangani surat tanda kepesertaannya ketika ingin meminjam uang/ dana dari pihak bank. Pencantuman klausula asuransi atau adanya polis asuransi adalah sebagai upaya preventif untuk menanggulangi risiko bank yang dapat terjadi seperti misalnya pencantuman klausula asuransi jiwa untuk menyikapi jika ada debitur meninggal dunia sebelum sempat melunasi semua angsuran kreditnya. Dalam hal debitur meninggal dunia sebelum sempat melunasi utang-utangnya pada bank, dengan adanya pencantuman klausula asuransi jiwa dalam hal ini dapat menjadi solusi untuk melunasi utang-utang debitur kebada bank selaku kreditur. Jadi disini pihak asuransilah yang bertanggungjawab terhadap utang-utang tertanggungnya, sehingga ahli waris tidak dibebani lagi. Maka karena hal tersebut asuransi sering dikatakan sebagai pertukaran yang tidak seimbang (aleatory contact), artinya ada kemungkinan beban yang ditanggung pihak asuransi kadang tidak seimbang dengan jumlah premi yang telah dibayarkan.

Ketika risiko terjadi maka pemegang polis akan mengajukan klaim asuransi tersebut, mekanisme pencairan dana asuransi yang mana preminya telah dibayarkan tiap bulannya bersamaan dengan pinjaman pokok biasanya pihak bank menggunakan metode banker's clause atau klausula bank. Jadi klausula ini dicantumkan sebagai akibat dari adanya hubungan hukum berupa utang-piutang antara debitur dengan kreditur dimana obyek pertanggungannya menjadi jaminan bank. Maka klausula ini bukan merupakan klausula baku dalam suatu perjanjian kredit ataupun asuransi, namun dalam keadaan hal tertentu saja dimintakan oleh bank yang bekerjasama kepada pihak asuransi guna memberikan perlindungan kepada pihak bank ketika memberikan pinjaman/kredit kepada nasabah debitur. Dari sinilah kita melihat adanya tangung jawab dari pihak asuransi kepada pihak ketiga yaitu ketika terjadi klaim terhadap asuransi tersebut, maka pihak asuransi harus mencairkan dana pihak tertanggung untuk dipergunakan sesuai dengan kepentingan dalam isi perjanjian yang telah dibuat sebelumnya.

Namun disamping hal tersebut diatas, bagaimana jika pihak asuransi tidak mau menerima klaim asuransi terhadapnya, maka tanggung jawab pihak asuransi dapat dituntut sesuai ketentuan UndangUndang No.40 tahun 2014 yaitu dalam pasal 52 UU Perasuransian ini menjelaskan bahwa kedudukan pemegang polis merupakan hal yang utama dan kedudukannya lebih tinggi dari pihak lainnya. (Alfiandi, 1993). Jangka waktu pembayaran klaim asuransi berdasarkan pasal 40 ayat (1) Peraturan OJK No.69/POJK/201627 yaitu selama 30 hari sejak disetujuinya permintaan klaim. Pihak asuransi harus bertanggungjawab terhadap kewajibannya serta hak pemegang polis dan tertanggung, karena jika tidak dapat dikenakan sanksi peringatan, pembatasan kegiatan usaha bahkan pencabutan izin usaha (pasal 37 PP 73/1992 tentang Penyelenggaraan Usaha Perasuransian). Hal ini berarti pihak asuransi telah melakukan wanprestasi karena tidak bertanggung jawab sesuai isi polis, namun harus dibuktikan terlebih dahulu, jika memang pihak asuransi benar lalai memenuhi kewajibannya terhadap tertanggung atau pun pemegang polis.

Karena hal tersebut, jika pihak asuransi tidak bertanggung jawab atas kewajiban yang ditanggungnya maka pemegang polis atau pihak nasabah debitur (ahli warisnya) dapat mengajukan gugatan atas tidak terlaksananya klaim untuk melunasi sisa utang debitur namun sebelum mengajukan 
gugatan wanprestasi, dilakukan upaya somasi atau teguran terlebih dahulu, jika tidak ada respon yang baik, maka dapat mengajukan gugatan perdata ke pengadilan umum. Disamping itu upaya mediasi juga dapat ditempuh melalui Badan Mediasi Asuransi Indonesia (BMAI).

Perlu diingat sekali lagi, bahwa setiap polis asuransi memiliki syarat dan ketentuan tersendiri. Sebagai contohnya dalam polis asuransi kredit multiguna PT. Asuransi Mitra Pelindung Mustika (MPM), walaupun batas tanggung jawab penanggung sebatas sisa pokok kredit yang tersisa, klaim tidak dapat diajukan jika tertanggung meninggal dunia karena sakit (bukan kecelakaan) dala masa 3 bulan setelah pertanggungan berlaku, terkait juga pekerjaan atau profesi tertanggung yang memiliki risiko besar seperti polisi, tentara, dan sejenisnya. Selanjutnya polis dapat di klaim jika pembayaran premi tidak mengalami tunggakan sama sekali. Jadi dari contoh syarat dan ketentuan tersebut, maka penting untuk mengetahui hak serta kewajiban para pihak yaitu penanggung, tertanggung dan bank selaku pemegang polis.

\section{SIMPULAN DAN SARAN}

\section{Simpulan}

Akibat Hukum Perjanjian Kredit dalam hal Debitur Meninggal Dunia. Mengingat sekian banyak risiko yang dapat terjadi dalam pemberian kredit oleh bank, salah satunya yaitu meninggalnya debitur ketika kredit masih berjalan. Jadi akibat hukum bagi perjanjian kreditnya terdapat dua kemungkinan yaitu perjanjian kredit hapus karena adanya jaminan asuransi jiwa dalam perjanjian kredit yang telah dibuat, serta kemungkinan kedua yaitu ahli waris sebagaimana pasal 833 KUHPerdata dengan sendirinya karena hukum berhak atas warisan serta piutang pewaris/debitur. Namun perlu diingat bahwa ahli waris memiliki hak berpikir apakah akan menerima sepenuhnya, menerima dengan syarat atau pun menolak warisan dari pewaris tersebut (pasal 1023 KUHPerdata). Kemudian, tanggung Jawab Pihak Asuransi Terhadap Perjanjian Kredit Bank Dalam hal Debitur Meninggal Dunia. Klausula asuransi jiwa menjadi hal penting mengingat asuransi merupakan lembaga peralihan risiko. Dengan adanya klausula asuransi jiwa serta perjanjian asuransi, pihak asuransi memiliki tanggung jawab untuk melunasi sisa utang debitur jikalau debitur meninggal dunia sebelum sempat melunasi sisa kreditnya. Ketika klaim terjadi maka pihak asuransi mencairkan dana dan dikirim langsung ke rekening bank dengan syarat banker's clause sehingga pembayaran sisa utang menjadi tujuan utamanya. Jika pihak asuransi menolak untuk bertangung jawab dan mengingkari kewajibannya, maka pihak yang berkepentingan dapat mengupayakan mediasi maupun somasi hingga melakukan gugatan perdata ke pengadilan, jika upaya somasi tidak diindahkan.

\section{Saran}

Kepada Pemerintah diharapkan mengoptimalkan produk hukumnya terkait pasal 833 KUHPerdata yang masih ada kekaburan norma, sehingga perlu diperjelas, bahwa norma pada pasal 833 KUHPerdata harus jalan berdampingan dengan pasal 1023 KUHPerdata, sehingga memberikan kepastian hukum bagi masyarakat, jika terjadi peristiwa seperti nasabah debitur meninggal dunia sebelum sempat melunasi sisa kreditnya. Selain itu produk hukum terkait perasuransian khususnya asuransi jiwa perlu dibuat khusus sehingga pengaturannya lebih mendetail dan rinci. Selanjutnya, kepada Pihak Bank, walaupun perjanjian kredit merupakan suatu perjanjian baku, namun isinya haruslah memiliki itikad baik serta tidak merugikan pihak lain. Selain itu pihak bank harus tetap menerapkan prinsip kehati-hatian serta melakukan analisis $5 \mathrm{C}$ sebelum memberikan kredit kepada calon nasabah debitur. Kemudian, kepada Pihak Asuransi yaitu disini adalah asuransi jiwa harus bertanggung jawab penuh terhadap perjanjian kredit yang telah dibuat yang tidak dapat dilepaskan dari perjanjian asuransi, sehingga jika terjadi klaim karena pemegang polis meninggal dunia, maka pihak asuransi harus mencairkan dana untuk melunasi sisa utang pemegang polis kepada pihak bank, untuk menghindari permasalahan hukum di kemudian hari. Terkahir, kepada masyarakat selaku calon nasabah debitur, mengingat perjanjian kredit merupakan perjanjian baku, para pihak khususnya calon nasabah debitur harus memahami betul isi perjanjian kredit yang ditetapkan sepihak oleh pihak bank, sehingga mengetahui segala konsekuensi dari kemungkinan-kemungkinan yang dapat terjadi, yang mana dapat merugikan secara materiil ataupun immaterial.

\section{DAFTAR PUSTAKA}

Ahmad, Beni. 2008. Metode Penelitian Hukum. Bandung: Pustakasetia. 
Gunartha, I. Putu Krisna Adi. 2013. "Penyelesaian Perjanjian Kredit Macet Akibat Wanprestasi Bagi Debitor Yang Meninggal Dunia Pada Bank Rakyat Indonesia Cabang Waingapu, Sumba Timur, Provinsi Nusa Tenggara Timur." Universitas Hasanuddin Makasar.

Indriani, Cheni Dwi. 2018. "Tanggung Jawab PNS Selaku Debitur Bank Yang Meninggal Dunia Terhadap Hutang-Hutangnya (Studi Pada Bank Mandiri Cabang Mataram).” Universitas Mataram.

Marzuki, Peter Mahmud. 2011. Penelitian Hukum. Jakarta: Kencana Prenida Media.

Mursid, Akhmad Faqih. 2018. "Perjanjian Kredit Yang Mencantumkan Kausula Asuransi Jiwa.” JUSTISI 4(2).

Pambudi, Dewi Ayu and Pujiyono. 2016. "Tanggungjawab Ahli Waris Debitur Dalam Kredit Dengan Jaminan Fidusia Di PT BNI Sentra Kredit Kecil Solo.” Privat Law IV(2).

Soekanto, Soerjono and Sri Mamudji. 2003. Penelitian Hukum Normatif: Suatu Tinjauan Singkat. Jakarta: PT. Raja Grafindo Persada.

Subekti, R. 2005. Hukum Perjanjian. Jakarta: Intermasa.

Suparman, Eman. 2018. Hukum Waris Indonesia Dalam Perspektif Islam. Bandung: PT. Refika Aditama. Undang-Undang Nomor 40 Tahun 2014 Tentang Perasuransian 